\title{
鉄骨構造露出柱脚におけるアンカーボルトのせん断抵抗力に関する実験的研究 EXPERIMENTAL STUDIES ON THE SHEAR RESISTANCE OF ANCHOR BOLTS IN EXPORSED TYPE OF STEEL COLUMN BASES
}

\author{
河野久夫*1, 九谷和秀*2, 増田貫志*3 \\ Hisao KAWANO, Kazuhide KUTANI and Kanshi MASUDA
}

\begin{abstract}
The authors have already reported the results of the study on the shear resistance of anchor bolt concerned with diameter of anchor bolt, side cover and edge distance to the concrete footing, when shearing forces act upon embedded anchor bolts. Considering the damage conditions of bolts in past earthquakes, in this paper the authors will analyze the failure characteristics of the anchorage of bolts and evaluate the ultimate strength when the bolt heads are subjected to tensile and shearing forces using the specimens whose distance from center of anchor shank to the edge of concrete footing is comparatively short.
\end{abstract}

Keywords : column base, anchor bolt, concrete footing, edge distance, shear resistance

柱脚, アンカーボルト, 基礎コンクリート, 縁端距離, せん断抵抗力

1.はじめに

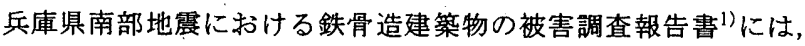
露出柱脚のアンカーボルトの破断ならびにベースプレート下のコン クリートの破壊により建物の倒壊あるいは大破を招いたものがかな り多く見受けられたことが報告されている。このような柱脚の損傷 に起因する地震被害を低減する方策として, アンカーボルト自体に 関しては，ねじ部の早期破断を防止し，十分な塑性変形能力を確保 する観点から，日本鎆構造協会によって建築構造用転造ねじアンカ 一ボルト・ナット・座金のセットが規格化 ${ }^{2)}$ れ，着実に普及し始 めているものと推察される。また，基磷コンクリートの著しい破壊 を防止する観点から引き抜きを受けるアンカーボルトの定着に関し ては，九谷ら ${ }^{3)}$, 三谷ら ${ }^{4)}$ の研究があり，既に研究成果の一部は鋼 構造接合部設計指針占に取り入れられている。

ところで，柱脚部には軸力，曲げモーメント以外にもせん断力が 作用しており，通常の設計では，せん断力はベースプレートとコン クリートの摩擦抵抗力あるいはアンカーボルトのだほ作用によって 基碟コンクリートに伝達されるとしている。しかし, 各種合成構造 設計指針)ならびに鋼構造接合部設計指針においても, アンカーボ ルトのせん断抵抗力と基礎コンクリートの縁端距離との関倸は明確 に述べられていない。従って, 引張力とせん断力の組み合わせ态力 を受けるアンかーボルト自体および定着される側の基礎コンクリー トの耐力評価式を得ることは未解決の重要な課題の一つと言える。

ここで, コンクリート中に埋め込まれたアンカーボルト等のカ学 性状に関する既往の研究として，以下のような研究成果がある。

Fisherら ${ }^{7)}$ は, 頭付きアンカーボルトに組み合わせ応力を作用さ
せた場合の耐力評価式を提案しているが，アンカーボルトの埋め込 み長さが軸径の約 $5 \sim 10$ 倍と比較的短い。 また, 松崎 $5^{8) 9}$ は, 機器 配管用支持楼造物の埋め込み金物の耐力に関する一連の実験を行 い，終局耐力に関する評価式を提案しているが，埋め込み長さは金 物の軸径に対して比較的短い。ついで; 河村ら ${ }^{10)}$ は，水平力を受け る埋め込み鉄筋の耐力評価に関する実験を行い，その耐力の推定式 を提案しているが，埋め込み長さは鉄筋径の約 $5 \sim 8$ 倍と比較的短 い。さらに, 細川 ${ }^{11}$ は，あと施エアンカーの定着機構を解明してい る。

しかしながら，上記の研究成果は，いずれもアンカーボルト軸径 に対する埋め込み長さが比較的短い場合の耐荷性状であり, 軸径の 20倍程度以上の埋め込み長さを要する鉄骨柱脚に用いるアンカーボ ルトの举動と直接対态させるには難点がある。

一方，鉄骨柱脚に用いるアンカーボルト等の力学性状に関する既 往の研究として, 以下のような研究成果がある。

Klingnerら ${ }^{12)}$ は，19 場合の実験を行い,. 縁端距離, ヘアピン補強，荷重条件等の影響を 検討するとともに，終局時のせん断耐力に関する評価式の検証を行 っている。また，秋山ら ${ }^{13)}$ は，㴊強な基礎コンクリートに埋め込ま れたアンカーボルトとシアプレートのせん断抵抗に基づく耐力評価 式を提案している。さらに，九谷ら ${ }^{14)}$ は，アンカーボルトのだぼ作 用により抵抗する基礎コンクリートのせん断耐力を既往の評価式を 用いて検証している。ついで, 中島ら ${ }^{15)}$ は, 引張力, せん断力およ びそれらの組み合わせ応力を受けるアンカーボルトの実験を行い, ねじ部，モルタル層および繰り返しせん断荷重の影響について検

\footnotetext{
*1 值)オフィスボンド 代表取締役

*2 九州産業大学工学部建築学科 助教授 $\cdot$ 工博

*3 九州産業大学工学部建築学科 教授・工博
}

Director, Office Bond Co., Inc.

Assoc. Prof., Dept. of Architecture, Faculty of Engineering, Univ. of Kyushu Sangyo, Dr. Eng.

Prof., Dept. of Architecture, Faculty of Engineering, Univ. of Kyushu Sangyo, Dr. Eng. 
表ー1 試験体一覧および実験結果

\begin{tabular}{|c|c|c|c|c|c|c|c|c|c|}
\hline $\begin{array}{c}\text { 試験体 } \\
\text { No. } \\
\end{array}$ & 名 称 & $\begin{array}{c}\mathrm{d} \\
(\mathrm{mm}) \\
\end{array}$ & $\begin{array}{r}\text { e } 1 \\
(\mathrm{~mm}) \\
\end{array}$ & $\begin{array}{c}\theta \\
\text { (度) } \\
\end{array}$ & $\frac{\mathrm{e}}{\mathrm{d}}$ & $\begin{array}{r}P \max \\
(\mathrm{KN}) \\
\end{array}$ & $\begin{array}{r}\text { Pcal } \\
(\mathrm{KN})\end{array}$ & $\frac{\text { Pmax }}{\text { Pcal }}$ & $\begin{array}{l}\text { 破買 } \\
\text { 形式 }\end{array}$ \\
\hline 1 & M12 & 10.67 & 40 & 0 & 3.75 & 8.24 & 9.50 & 0.87 & 1 \\
\hline 2 & $\mathrm{Ml} 2$ & 10.66 & 40 & 30 & 3.75 & 7.85 & 10.89 & 0.72 & 1 \\
\hline 3 & $\mathrm{M} 12$ & 10.66 & 40 & 45 & 3.75 & 11.28 & 13.15 & 0.86 & 1 \\
\hline 4 & M12 & 10.66 & 40 & 60 & 3. 75 & 17.16 & 17.88 & 0.96 & 1 \\
\hline 5 & M12 & 10.65 & 40 & 90 & 3.76 & 49.72 & 45.78 & 1.09 & 5 \\
\hline 6 & $\mathrm{M} 12$ & 10.65 & 50 & 0 & 4.69 & 10.20 & 12.66 & 0.81 & 1 \\
\hline 7 & $\mathrm{M} 12$ & 10.66 & 50 & 30 & 4.69 & 8.14 & 14.43 & 0.56 & 1 \\
\hline 8 & M12 & 10.65 & 50 & 45 & 4. 69 & 11.96 & 17.25 & 0.69 & 1 \\
\hline 9 & $M 12$ & 10.66 & 50 & 60 & 4. 69 & 15.40 & 22.83 & 0.67 & 1 \\
\hline 10 & M12 & 10.66 & 50 & 90 & 4. 69 & 47.86 & 45.78 & 1.05 & 5 \\
\hline 11 & $\mathrm{M} 12$ & 10.66 & 60 & 0 & 5.63 & 12. 36 & 16.13 & 0.77 & 1 \\
\hline 12 & $M 12$ & 10.65 & 60 & 30 & 5.63 & 16.67 & 18.25 & 0.91 & 2 \\
\hline 13 & $\mathrm{M} 12$ & 10.66 & 60 & 45 & 5.63 & 16.97 & 21.51 & 0.79 & 2 \\
\hline 14 & M12 & 10.66 & 60 & 60 & 5.63 & 21.87 & 27.53 & 0.79 & 1 \\
\hline 15 & M12 & 10.65 & 60 & 90 & 5.63 & 50.80 & 45.78 & 1.11 & 5 \\
\hline 16 & M12 & 10.66 & 100 & 90 & 9. 38 & 51.09 & 45.78 & 1.12 & 5 \\
\hline 17 & M12 & 10.66 & 120 & 90 & 11.26 & 50.01 & 45.78 & 1.09 & 5 \\
\hline 18 & M12 & 10.66 & 200 & 0 & 18.76 & 36.97 & 27.98 & 1. 32 & 4 \\
\hline 19 & $\mathrm{Ml2}$ & 10.65 & 200 & 30 & 18.78 & 33.15 & 30.47 & 1.09 & 4 \\
\hline 20 & $M 12$ & 10.65 & 200 & 45 & 18.78 & 37.76 & 33.72 & 1.12 & 4 \\
\hline 21 & $\mathrm{M} 12$ & 10.66 & 200 & 60 & 18.76 & 42.17 & 38.42 & 1.10 & 4 \\
\hline 22 & M12 & 10.66 & 200 & 90 & 18.76 & 48.05 & 45.78 & 1.05 & 5 \\
\hline 23 & $\mathrm{~W} 1 / 2$ & 12.90 & 80 & 0 & 6.20 & 26.38 & 28.08 & 0.94 & 3 \\
\hline 24 & $\$ 1 / 2$ & 12.94 & 90 & 0 & 6.96 & 26.87 & 33.24 & 0.81 & 3 \\
\hline 25 & $W 1 / 2$ & 12.88 & 100 & 0 & 7. 76 & 32.26 & 36.52 & 0.88 & 2 \\
\hline 26 & $W 1 / 2$ & 12.89 & 110 & 0 & 8.53 & 43.05 & 36.02 & 1.20 & 4 \\
\hline 27 & $\mathrm{~W} 1 / 2$ & 12.94 & 130 & 0 & 10.05 & 42.07 & 36.29 & 1.16 & 4 \\
\hline 28 & $\mathrm{Wl} / 2$ & 12.88 & 80 & 45 & 6.21 & 34.68 & 32.96 & 1.05 & 3 \\
\hline 29 & $W 1 / 2$ & 13.01 & 90 & 45 & 6.92 & 41.19 & 36.79 & 1.12 & 4 \\
\hline 30 & $\mathbb{N 1 / 2}$ & 12.89 & 100 & 45 & 7. 76 & 50.80 & 38.58 & 1.32 & 4 \\
\hline 31 & T $1 / 2$ & 12.86 & 110 & 45 & 8.55 & 45.41 & 43.15 & 1.05 & 4 \\
\hline 32 & $\$ 1 / 2$ & 12.80 & 120 & 45 & 9.38 & 50.60 & 38.27 & 1.32 & 4 \\
\hline 33 & $\mathrm{~W} 1 / 2$ & 12.77 & 130 & 45 & 10.18 & 49.82 & 38.16 & 1.31 & 4 \\
\hline 34 & M16 & 15.60 & 50 & 0 & 3.21 & 12.95 & 15.27 & 0.85 & 1 \\
\hline 35 & M16 & 15.58 & 50 & 30 & 3.21 & 12.16 & 17.50 & 0.69 & 1 \\
\hline 36 & Ml6 & 15.58 & 50 & 45 & 3.21 & 16. 38 & 21.11 & 0.78 & 1 \\
\hline 37 & Ml 6 & 15.56 & 50 & 60 & 3.21 & 30.99 & 28.62 & 1.08 & 1 \\
\hline 38 & M16 & 15.58 & 50 & 90 & 3.21 & 73.45 & 70.96 & 1.04 & 5 \\
\hline 39 & MI6 & 15.58 & 60 & 0 & 3.85 & 15.99 & 19.46 & 0.82 & 1 \\
\hline 40 & M16 & 15.62 & 60 & 30 & 3.84 & 16.48 & 22.19 & 0.74 & 1 \\
\hline 41 & $M 16$ & 15.63 & 60 & 45 & 3. 84 & 19.12 & 26.54 & 0.72 & 1 \\
\hline 42 & $M 16$ & 15.60 & 60 & 60 & 3.85 & 27.16 & 35.16 & 0.77 & 1 \\
\hline 43 & M16 & 15.64 & 70 & 0 & 4. 48 & 19.32 & 24.03 & 0.80 & 2 \\
\hline 44 & M16 & 15.57 & 70 & 30 & 4. 50 & 17.95 & 27.23 & 0.66 & 1 \\
\hline 45 & M16 & 15.62 & 70 & 45 & 4. 48 & 26. 38 & 32.19 & 0.82 & 1 \\
\hline 46 & M16 & $15.59^{\circ}$ & 70 & 60 & 4. 49 & 30.11 & 41.45 & 0.73 & 1 \\
\hline 47 & $M 16$ & 15.62 & 200 & 0 & 12.80 & 72.47 & 50.01 & 1.45 & 4 \\
\hline 48 & M16 & 15.61 & .200 & 30 & 12. 81 & 71.88 & 53.43 & 1.35 & 4 \\
\hline 49 & M16 & 15.59 & 200 & 45 & 12.83 & 75.41 & 57.66 & 1.31 & 4 \\
\hline 50 & $M 16$ & 15.61 & 200 & 60 & 12.81 & 82.47 & 63.35 & 1.30 & 4 \\
\hline 51 & M16 & 15.59 & 200 & 90 & 12.83 & 73.45 & 70.96 & 1.04 & 5 \\
\hline 52 & M20 & 19.70 & 70 & 0 & 3.55 & 19.71 & 22.65 & 0.87 & 3 \\
\hline 53 & M20 & 19.76 & 70 & 30 & 3.54 & 20.59 & 25.98 & 0.79 & 1 \\
\hline 54 & M20 & 19.72 & 70 & 45 & 3.55 & 24.52 & 31.40 & 0.78 & 3 \\
\hline 55 & $\mathrm{M} 20$ & 19.71 & 70 & 60 & 3.55 & 43.93 & 42.75 & 1.03 & 3 \\
\hline 56 & M20 & 19.69 & 80 & 0 & 4. 06 & 23.83 & 27.32 & 0.87 & 2 \\
\hline 57 & M20 & 19.72 & 80 & 30 & 4. 06 & 25.40 & 31.23 & 0.81 & 2 \\
\hline 58 & M20 & 19.69 & 80 & 45 & 4. 06 & 34.62 & 37.53 & 0.92 & 2 \\
\hline 59 & $\mathrm{M} 20$ & 19.58 & 80 & 60 & 4.09 & 43.74 & 50.31 & 0.87 & 3 \\
\hline 60 & M20 & 19.69 & 90 & 0 & 4. 57 & 26.67 & 32.34 & 0.82 & 2 \\
\hline 61 & M20 & 19.64 & 90 & 30 & 4. 58 & 27.26 & 36.83 & 0.74 & 2 \\
\hline 62 & M20 & 19.65 & 90 & 45 & 4.58 & 33.34 & 43.93 & 0.76 & 2 \\
\hline 63 & $\mathrm{M} 20$ & 19.64 & 90 & 60 & 4.51 & 49.72 & 57.82 & 0.86 & 3 \\
\hline 64 & M20 & 19.62 & 100 & 30 & 5.10 & 33.25 & 42.74 & 0.78 & 3 \\
\hline 65 & $\mathrm{M} 20$ & 19.70 & 100 & 45 & 5.08 & 37.46 & 50.53 & 0.74 & 2 \\
\hline
\end{tabular}

証している。

本論文では, 著者らの一連の研究結果 ${ }^{(6)}$ に追加して, 特に 基礎コンクリートの縁端距離が短い場合を含む新たな実験 ${ }^{17)}$ を行い，引張力またはせん断力のいずれか一方，むるいはそれ らの組み合わせ応力を受けるアンカーボルトについで, 柱脚部の 破壊形式の分類および終局時のせん断抵抗力に関する研究成 果を報告するものである。なお, 引張力とせん断力の組み合わせ 応力は立ち上がり部を有する基礎コンクリートの，また，純せん断 カは基礎コンクリート全般の応力状態を想定したものである。

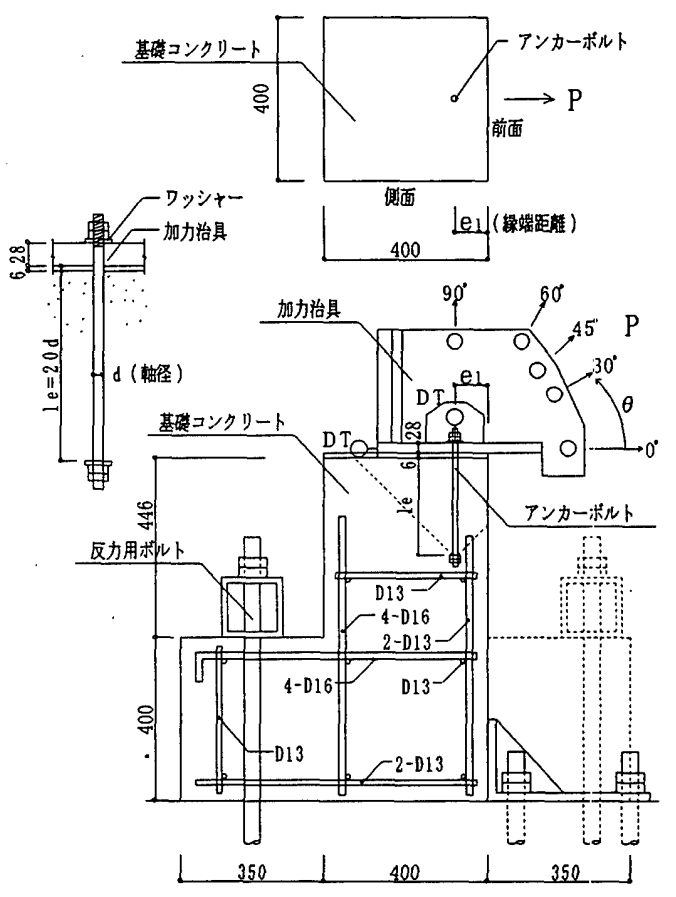

図ー1 試験体および加力装置

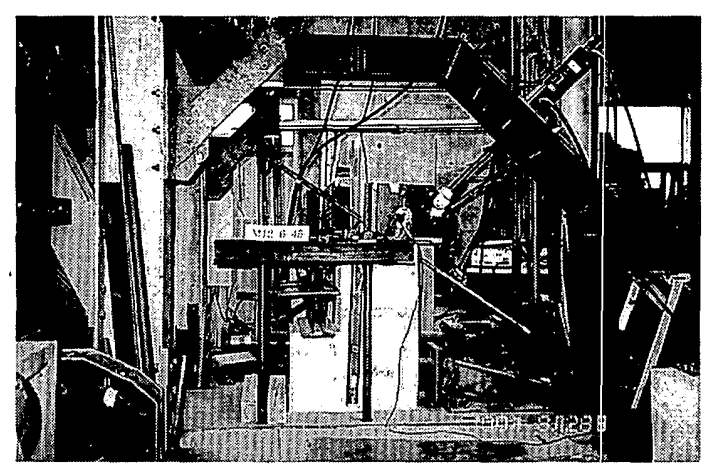

写真 -1 加力状況

\section{2. 試験体およひ実験概要}

試験体一覧を表一1，試験体および加力装置を図ー1，加力 状況を写真一1に示す。試験体は，アンカーボルトねじサイ ズ毎のシリーズに分け，M12，W1/2，M16およびM20シリーズ について，それぞれ22，11，18，14体の合計65体を作製した。

アンカーボルトの材質は全てSS400とし，M12は転造ねじ, W1/2, M16およびM20は切削ねじとした。アンカーボルトの埋め 込み長さleは学会指針 ${ }^{5)}$ に準拠し，呼び径とねじサイズのうち大き 
い方の值の20倍程度とした。なお, 全てのアンカーボルトは, 埋め込み先 端部にアンカープレート $(\phi \times t, \phi$ : 直径, $t$ : 板厚 $)$ を有し, M12,W1/2，M16，M20の順に，それぞれ30×12，35×12，40×12， $50 \times 16$ とした。また，ねじ部でのせん断破壊を避けるためアンカー

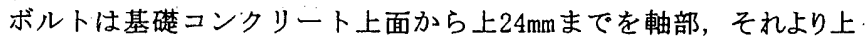
をねじ部とした。

本実験において，アンカーボルト中心から基礎コンクリート縁ま での縁端距離 $\mathrm{e} 1$ は $40 \mathrm{~mm} \sim 200 \mathrm{~mm}$ とし, 基礎コンクリートの幅は試験 体の最大縁端距離の 2 倍の $400 \mathrm{~mm}$ とした。基礎コンクリートの形状 は, 加力方向 $\theta$ が $0^{\circ} \sim 60^{\circ}$ の試験体をL形とし， $\theta=90^{\circ}$ の試験体を逆 $\mathrm{T}$ 形(図一1中に破線で示す)とした。なお，基碳コンクリート内の 補強筋は加力時の曲げモーメントや運搬時の応力に抵抗させるため であり，実験結果に影響を及ぼさないように配慮した。

基礎コンクリートにはレディーミグストコンクリート(普通ポル トランドセメント)を使用し，骨材の最大寸法は $20 \mathrm{~mm}$ 以下とした。 また, 鋼材の引張試験結果を表一 2 に, コンクリートの性状を表 -3 に示す。

表一2 鋼材の引張試験結果

\begin{tabular}{|c|c|c|c|c|c|c|}
\hline \multirow[t]{2}{*}{ 銅材 } & \multirow[t]{2}{*}{ 呼び径 } & \multirow[t]{2}{*}{ 鋼種 } & \begin{tabular}{|c|} 
降伏強度 \\
$\sigma . \mathrm{y}$
\end{tabular} & \multirow{2}{*}{$\begin{array}{c}\text { 引張強度 } \\
\sigma \mathrm{u} \\
\left(\mathrm{N} / \mathrm{mm}^{2}\right)\end{array}$} & \multirow{2}{*}{$\begin{array}{l}\text { 伸び } \\
(\%)\end{array}$} & \multirow{2}{*}{ 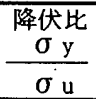 } \\
\hline & & & $\left(\mathrm{N} / \mathrm{mm}^{2}\right)$ & & & \\
\hline \multirow{4}{*}{ アンカーボルト } & $12 \phi$ & \multirow{4}{*}{$\operatorname{SS} 400$} & 491 & 543 & 11 & 0.90 \\
\hline & $13 \phi$ & & 341 & 478 & 28 & 0.71 \\
\hline & $16 \phi$ & & 308 & 452 & 34 & 0.68 \\
\hline & $20 \phi$ & & 325 & 456 & 32 & 0.71 \\
\hline \multirow{2}{*}{ 補強筋 } & D 13 & \multirow{2}{*}{ SD295A } & 326 & 488 & 29 & 0.67 \\
\hline & D16 & & & & 26 & \\
\hline
\end{tabular}

表ー3 コンクリートの性状

\begin{tabular}{|c|c|c|}
\hline 適 用 & $\begin{array}{c}\text { 圧縮強度 } \\
F^{2} \\
\left(\mathrm{~N} / \mathrm{mm}^{2}\right)\end{array}$ & $\begin{array}{c}\text { スランプ } \\
(\mathrm{mm})\end{array}$ \\
\hline M12シリーズ & 20.4 & 78 \\
\hline W1/2シリース & 27.9 & 155 \\
\hline M16シリーズ & 29.7 & 104 \\
\hline M20シリーズ & 26.4 & 172 \\
\hline
\end{tabular}

加力装置ならびに加力状沉は，図ー1および写真一1に示す通りで あり，基磷コンクリートを鋼製ベッドに固定し，加力治具を介して アンカーボルトに $\theta=0^{\circ}, 30^{\circ} ， 45^{\circ} ， 60^{\circ} ， 90^{\circ}$ の方向に加力を行っ た。アンカーボルトは二重ナットのうえに手締めとし，加力治具と 基礎コンクリート上面間の摩擦抵抗を減少させるため, テフロン加 工鋼板（板厚 $6 \mathrm{~mm}$, 摩擦倸数0.06) を加力治具下面に敷き, $295 \mathrm{kN}$ 油圧 ジャッキ(295kNロードセル付き)を用いて破壊に至るまでの単調載 荷実験を行った。なお, アンカーボルト頂部の水平および鉛直変位 は電気式変位計を用いて約 980 刻みで測定した。

\section{3. 実験結果および考察}

\section{3-1. 破壊形式の分類}

著者らの一連の実験結果 ${ }^{16}$ および今回の実験結果から柱脚部の破 壊は表ー4に示すように5つの形式に分類できる。なお，各試験体の 破填形式をそれぞれ表ーIに示す。

\section{3-1-1. 破壊形式1}

基礎コンクリート前面が半棈円状に剥離する破壊を破壊形式1 と し，図ー2および写真一2に示す。試験体数は表ー4に示すように22

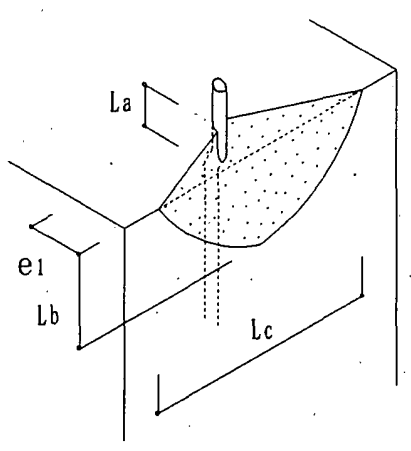

図-2 破壊模式図(形式1)

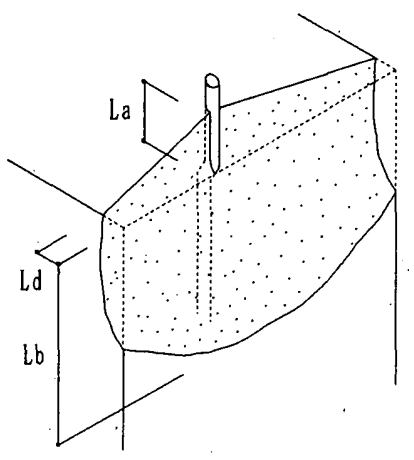

図-3 破填模式図(形式2)

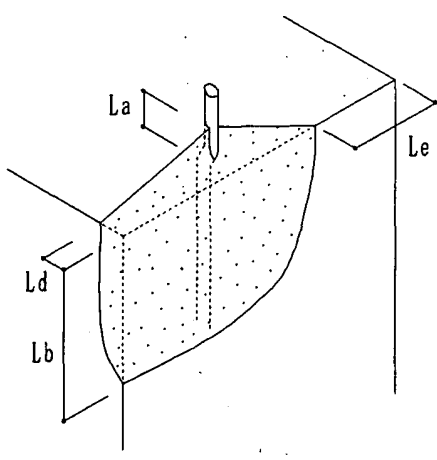

図-4破壊模式図(形式3)

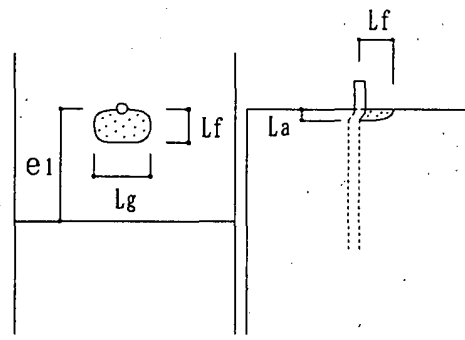

図-5 破壊模式図 (形式4)

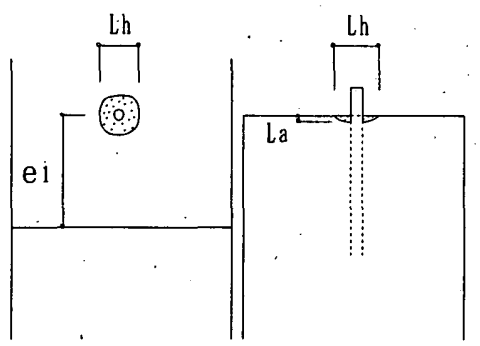

図-6，破壊模式図 (形式5)

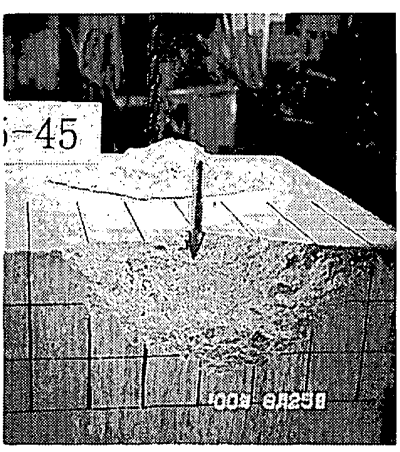

写真-2 破壊状況 (形式1)

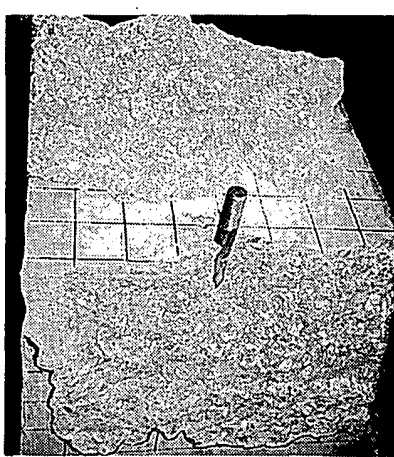

写真－3 破壊状況 (形式2)

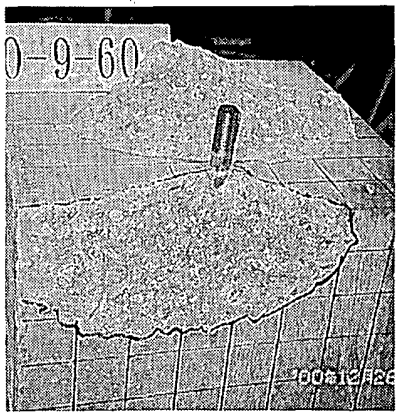

写真-4 破壊状況 (形式3)

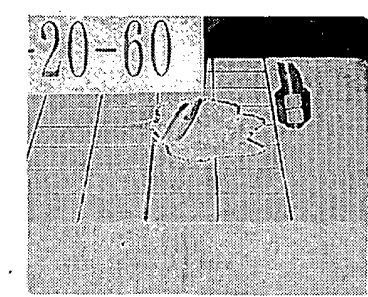

写真－5 破壊状況 (形式4)

M16-5-90

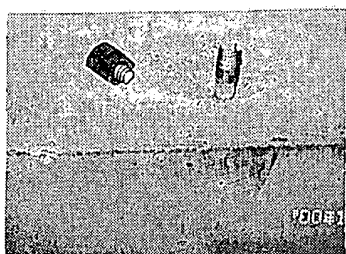

写真－6 破壊状況 (形式5) 
体である。基碟内部を起点として水平移動したアンカーボルト部分 の長さ $\mathrm{La}$ の平均值は3.1d となっている。また，基礎コンクリート 前面の破填した長さ Lbの平均值は $1.8 \mathrm{el}$ であり, 加力方向 $\theta$ 大゙大き くなる程Lbは小さくなる傾向がみられた。さらに，基礎コンクリー 卜前面の破壊幅Lcは3.5〜7.0 e1の範囲にあり，平均値は5.1 elとな っている。縁端距離の平均值が4. 1d と比較的短い試験体がこのよう な破壊を起こした。

\section{3-1-2. 破壊形式2}

基礎コンクリート前面が長方形状に剥離する破壊を破壊形式2 と し，図ー3および写真一3に示す。試験体数は11体である。Laの平均 值は3.1dであり，Lbの平均值は1.9e1となっている。また，加力方 向 $\theta$ が大きくなる程Lbは小さくなる傾向がみられた。これらの值は いずれも破壊形式1と似かよっている。基礎コンクリート上面端部 の破壊した長さ Ldは 5 〜 $63 \mathrm{~mm}$ の範囲にあり，平均值は $41 \mathrm{~mm}$ となっ いる。このような破壊を起こした試験体のうちの7体はM20シリーズ であった。縁端距離が4.1〜7.8dの範囲で平均值は5.0d と破壊形式1 に比べ若千大きく，また，アンカーボルトの剛性が大きい試験体が このような破壊を起こした。

\section{3-1-3. 破壊形式3}

破壊形式 1 と 2 の複合破壊を破壊形式 3 とし，図一 4 および写真一 4 に示す。試験体数は9体である。Laの平均值は1.9dであり破壊形式 1，2と比較するとやや短くなっている。また，Lbの平均值は $2.1 \mathrm{el}$ であり，加力方向 $\theta$ が大きくなる程Lbは小さくなる傾向がみられ た。なお，Ldは20～75mmの範围にあり，平均值は34mmとなってい る。これらは破壊形式2と似かよっている。さらに，基礎コンクリ 一ト前面端部から破壊面までの長さLe は0～90mmの範囲にあり，平 均值は $42 \mathrm{~mm}$ となっている。このような破壊を起こした試験体の縁端 距離の平均值は4.9dであり，破壊形式2 とほぼ同じ值である。

\section{3-1-4. 破壊形式4}

せん断力またはせん断力と引張力の組み合わせ态力によるアンカ 一ボルト破断を破壊形式 4 とし，図ー5および写真一5に示す。その うち，軸部で破断したものが13体，ねじ部で破断したものが No. 29，31の2体である。加力の初期段階では，加力方向のアンカー ボルト近傍のコンクリート表面にちびり破壊を生じた。その後は， コンクリート表面にひび割れの発生は認められず，荷重のみが増大 し，アンカーボルトが破断した。Laの平均值は1.1dであり，コンク リートで破壊した破填形式!〜3と比較するとかなり小さくなってい る。また，加方方のコンクリート表面の剥離幅 Lf の平均值は

$56 \mathrm{~mm}$ であり, 横方向の剥離幅 Lg の平均值は $91 \mathrm{~mm}$ とっている。縁 端距離が $6.9 \mathrm{~d}$ 以上で，加力方向 $\theta$ ガ $0^{\circ} \sim 60^{\circ}$ の試験体がこのような 破壊を起こした。

\section{3-1-5. 破壊形式5}

純引張力によるアンカーボルト破断を破壊形式5とし，図一6およ び写真一6に示す。アンカーボルトの破断はねじ部で破楽したもの が6体，軸部で破断したものが2体となっている。軸部で破断した試 験体はNo.17，22でいずれもM12の転造ねじボルトである。アンカー ボルトが引張力を受けて, 加力の初期段階ではアンカーボルト周辺 のコンクリート表面がほぼ円形状に剥離し, その後アンカーボルト が破断して最大荷重に達した。Laの平均值は0.9dである。また，ア ンカーボルト周辺のコンクリートの剥離した円形状の直径Lhの平 均値は $7 \mathrm{lmm}$ とっている。

\section{3-2. 耐力評価}

\section{3-2-1. 純引張力を受ける場合}

アンカーボルトの引張耐力に及ぼす基礎コンクリート縁端距離の 影響を調べるための試験体No. $5 ， 10 ， 15 ， 16 ， 17 ， 18 \sigma 66$ 体と，縁 端距離は十分あり，アンカーボルトが破断すると考えられるNo. 5, 22の2体の合計8体に純引張力を加える実験を行った。

ここで, 純引張力を受けるアンカーボルトの終局引張耐力 Tu は, 学会指針 ${ }^{6)}$ の各種アンカーボルトの設計指針・同解説に示され る耐力評価式を準用した (1) 式で求めた。すなわち, 鉄骨構造露出 柱脚に適用するためには，アンカーボルトに変形能力を持たせる観 点から基礎コンクリートの破壊を避け，基礎コンクリートのコーン 状破壊により決まる終局引張耐力 $\mathrm{T}_{1}$ ， アンカープレートに接するコ ンクリートの支圧により決まる終局引張耐力 $\mathrm{T}_{3}$ がアンカーボルト の破断により決まる終局引張耐力 $\mathrm{T}_{2}$ を上回る必要があるとした。

$$
\begin{aligned}
& \mathrm{Tu}=\mathrm{T}_{2} \\
& \text { ただし, } T_{2}<\min \left(T_{1}, T_{3}\right) \\
& \text { ここに， } \mathrm{T}_{1} \text { ：基礎コンクリートのコーン状破壊により決まる } \\
& \text { 場合のアンカーボルト1本当りの終局引張耐力 } \\
& \text { (N) } \\
& T_{1}=0.313 \phi_{1} A c \sqrt{F c} \\
& \phi_{1}=0.6\left(\phi_{1}: \text { 低減係数 }\right) \\
& \mathrm{T}_{2} \text { ：アンカーボルトの破断により決まる場合のアン } \\
& \text { カーボルト1本当りの終局引張耐力 }(\mathbb{N}) \\
& \mathrm{T}_{2}=\mathrm{b} \sigma \mathrm{u} \cdot \mathrm{bAe} \\
& \mathrm{T}_{3} \text { ：アンカープレートに接するコンクリートの支圧 }
\end{aligned}
$$

\begin{tabular}{|c|c|c|c|c|c|c|c|c|}
\hline \multirow{2}{*}{\multicolumn{2}{|c|}{ 分類 }} & \multirow{2}{*}{ 破填状況 } & \multicolumn{2}{|c|}{ 実験変数 } & \multicolumn{3}{|c|}{ 破壊面の寸法 } & \multirow{2}{*}{ 個数 } \\
\hline & & & $e 1 / d$ & $\theta$ & $\mathrm{La} / \mathrm{d}$ & $\mathrm{Lb} / \mathrm{el}_{1}$ & $\mathrm{Lc} / \mathrm{el}_{\mathrm{l}}$ & \\
\hline \multirow{5}{*}{$\begin{array}{l}\text { 破 } \\
\text { 壞 } \\
\text { 形 } \\
\text { 式 }\end{array}$} & 1 & 基礎コンクリート前面の半棈円状破壊 & $\begin{array}{c}3.2 \sim 5.6 \\
(4.1)\end{array}$ & $0^{\circ} \sim 60^{\circ}$ & $\begin{array}{c}1.0 \sim 6.1 \\
(3.1)\end{array}$ & $\begin{array}{c}1.0 \sim 3.0 \\
(1.8)\end{array}$ & $\begin{array}{c}3.5 \sim 7.0 \\
(5.1)\end{array}$ & $\begin{array}{c}22 \\
{[5]}\end{array}$ \\
\hline & 2 & 基礎コンクリート前面の長方形状破填 & $\begin{array}{l}4.1 \sim 7.8 \\
(5.0)\end{array}$ & $0^{\circ} \sim 45^{\circ}$ & $\begin{array}{l}1.5 \sim 6.1 \\
(3.1)\end{array}$ & $\begin{array}{l}1.6 \sim 2.9 \\
(1.9)\end{array}$ & - & $\begin{array}{l}11 \\
{[4]}\end{array}$ \\
\hline & 3 & 形式1 と2の複合破壊 & $\begin{array}{c}3.6 \sim 7.0 \\
(4.9)\end{array}$ & $0^{\circ} \sim 60^{\circ}$ & $\begin{array}{c}1.0 \sim 3.3 \\
(1.9)\end{array}$ & $\begin{array}{c}0.9 \sim 3.7 \\
(2.1)\end{array}$ & - & $\left.\begin{array}{c}9 \\
{[3]}\end{array}\right]$ \\
\hline & 4 & せん断力、または引張力とせん断力によるアンカーボルトの破断 & $6.9 \sim 18.8$ & $0^{\circ} \sim 60^{\circ}$ & $\begin{array}{c}0.2 \sim 2.8 \\
(1.1)\end{array}$ & - & -1- & $\begin{array}{l}15 \\
{[4]}\end{array}$ \\
\hline & 5 & |引張力によるアンカーボルトの破断 & $3.2 \sim 18.8$ & $90^{\circ}$ & $\begin{array}{c}0.7 \sim 1.2 \\
(0.9)\end{array}$ & - & - & 8 \\
\hline
\end{tabular}

（）内は平均值を示し，〔 〕内は純せん断を受ける試験体数を示す。 
により決まる場合のアンカーボルト1本当りの 終局引張耐力 $(\mathrm{N})$

$\mathrm{T}_{3}=\mathrm{fn} \cdot \mathrm{Ao}$

$\mathrm{Fc}$ ：コンクリートの圧縮強度 $\left(\mathrm{N} / \mathrm{mm}^{2}\right)$

Ac ：コンクリートのコーン状破壊面の有勃承平投影面

積 $\left(\mathrm{mm}^{2}\right)$

Ao ：アシカープレートの支圧面樌 $\left(\mathrm{mm}^{2}\right)$

$\mathrm{b} \sigma \mathrm{u}:$ アンカーボルト鋼材の引張強度 $\left(\mathrm{N} / \mathrm{mm}^{2}\right)$

bAe : アンカーボルトの軸断面積とねじ部有効断面積 (JISB1051)のうち小さい方の值をとる $\left(\mathrm{mm}^{2}\right)$ 。

fn ：コンクリートの支压強度で $\sqrt{\mathrm{Ac} / \mathrm{Ao}} \cdot \mathrm{Fc}$ とする $\left(\mathrm{N} / \mathrm{mm}^{2}\right)$ 。

ただし， $\sqrt{\mathrm{Ac} / \mathrm{Ao}}$ が10を超えるときは10とする。

本実験においては, アンカーボルトの埋め込み長さは $20 \mathrm{~d}$ と比較 的長く, $T_{2}<\min \left(T_{1}, T_{3}\right)$ の条件を満たしており，純引張力を受ける 全ての試験体はコンクリートのコーン状破壊を起こすことなく，ア ンカーボルトの破断により最大荷重に達している。なお，表一1に 示すように, 実験耐力P $\max$ と計算耐力Pcal (=Tu)の比Pmax/Pcal は1.04〜1.12を示しており，その平均値は1.07であり，実験耐力と 計算耐力は比較的よく対応していると言える。

以上から, 引張力を受けるアンカーボルトの終局引張耐力Tuは 学会式を準用した(1)式により評価できることが確認された。

\section{3-2-2. 純せん断力を受ける場合}

純せん断力を受けるアンカーボルトについての研究結果は文献 16）に報告済みであるが，再現性を確認するため特に基礎コンクリ ートの縁端距離が短い場合について追加実験を行った。

本実験では, 試験体16体中アンカーボルトにより基礎コンクリー トがパンチングシアー破壊し，最大荷重に達した試験体はNo.1， $6,11,23 \sim 25,34,39,43,52,56,60$ の 12 体である。それらの 破壊状況は, 破壊形式1 3に示寸通りである。一方, アンカーボル トがせん断破買を起こし, 最大荷重に達した試験体はNo. 18，26, 27，47の4体であり，その破壊状況は破壊形式4に示す通りである。 学会指針南では, アンカーボルトがせん断力を受けて, 基礎コン クリートがパンチングシアー破壊する場合の終局せん断耐力 cQu の 評価式として(2)式が示されている。

$\mathrm{cQu}=0.313 \mathrm{Aco} \sqrt{\mathrm{Fc}}$

ここに, Aco : 有勃投影面積 (半円, $\mathrm{mm}^{2}$ )

ところで，鉄骨構造露出柱脚に用いるアンカーボルトの埋め込 み長さは20d程度と比較的長く, 有効投影面積Acoについては実状に 合うように検討する必要がある。図一7に，elが50〜275mmでアン カーボルト径が $13 \phi \sim 56 \phi$ の 45 体 ${ }^{18)}$ と, 今回追加した $\mathrm{e} 1$ が $40 \sim$ $100 \mathrm{~mm}$ でアンカーボルト径が $12 \phi \sim 20 \phi$ の 12 体の合計57体について のAco一el関係を示す。なお，図中のAcoの值はP maxを $0.313 \sqrt{\mathrm{Fc}}$ で 除して求めた。

$\mathrm{Aco}=1.109 \mathrm{el}^{2}+123.6 \mathrm{el}$
図ー7より，(3)式で表わされるAco一el関係は実験結果と高い相 関 $\left(\mathrm{R}^{2}=0.97\right)$ が認められる。なお，参考のため今回の実験の中から 一例として，純せん断力を受けて基礎コンクリートが破壊した12体 について，コンクリート前面における破壊面積の実測值Ac と elの 関係を図ー8に示す。この面樌にはコンクリート表面が薄く広く剥 離した部分も含まれるため，かなりのバラッキが生じ; また，半円 (図中の破線)および(3)式(図中の実線)で表わされる有効投影面樌 と比較して極めてかけ離れた值を示している。見時点では,.実際の 破壊面積から耐力を予測するのは困難と考えられる。

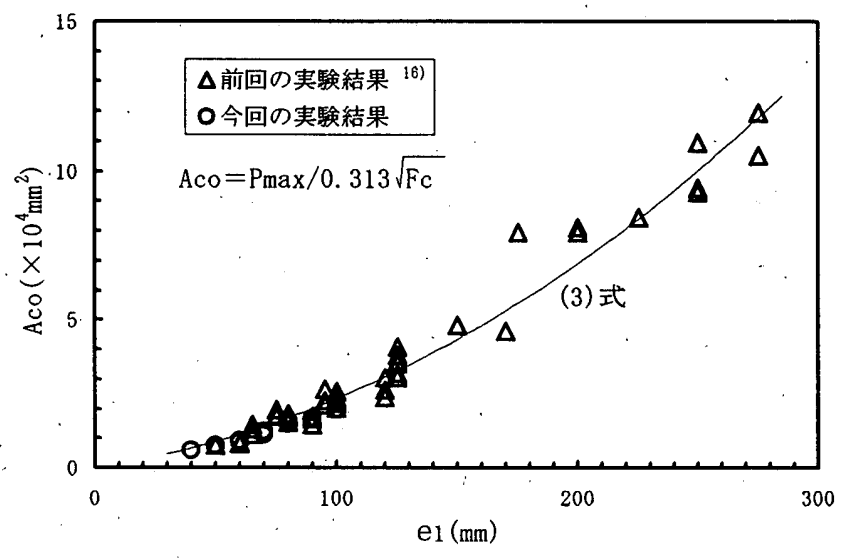

図 -7 Aco- $\mathrm{el}$ 関係
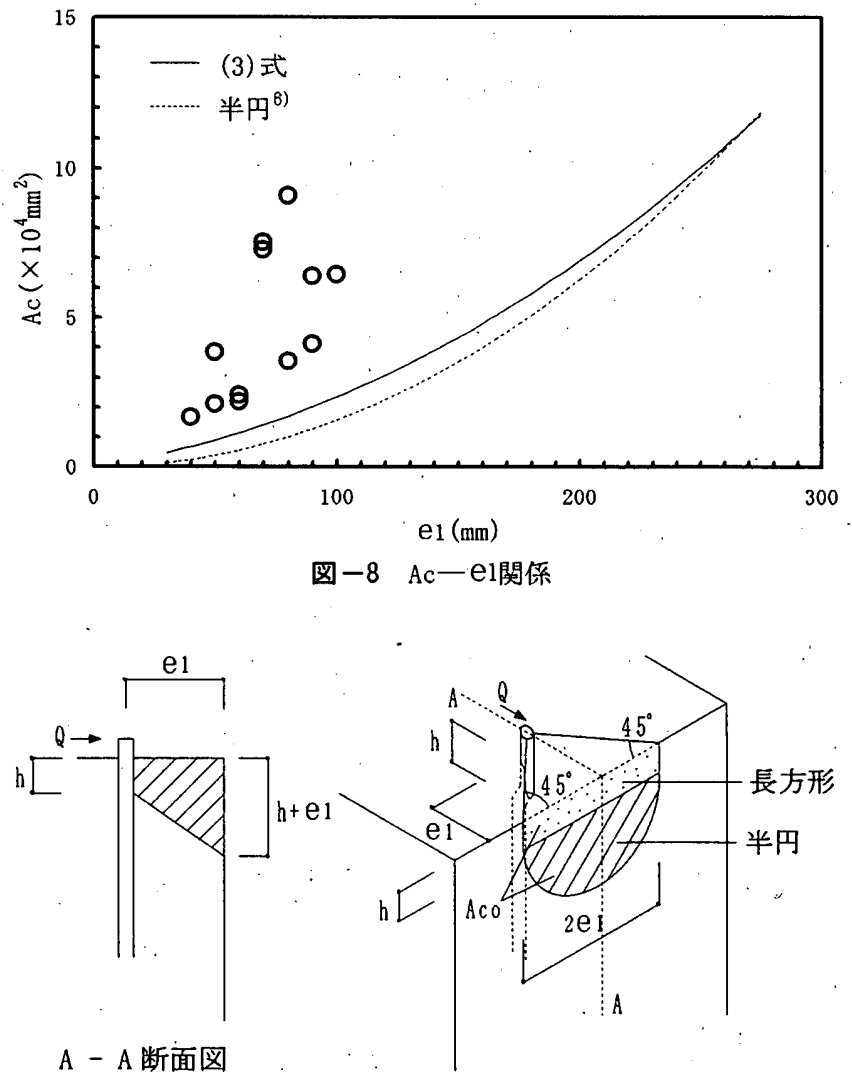

図－9 有効投影面積 (Aco)

実用設計では有効投影面積の簡便な作図法が要求されることか ら，本論文では，図ー9に示すように基礎コンクリート中における 応力が $45^{\circ}$ 方向に作用寸るものと仮定し，また，コンクリート上面 
から哚さhまでのアンカーボルトを投影した面積，すなわち長方形 と半円からなる面稹を有効投影面積と想定した。

図-9の有効投影面積は(4) 式で表わされ，この場合の長方形部分 の高さhは(3)式と(4)式を等值して(5)式のように得られる。

$$
\begin{array}{ll}
\mathrm{Aco}=\pi \mathrm{el}^{2} / 2+2 \mathrm{el} \cdot \mathrm{h} & \text { ただし, } 40 \mathrm{~mm} \leqq \mathrm{e} 1 \leqq 275 \mathrm{~mm} \\
\mathrm{~h}=61.8-0.23 \mathrm{el} & \text { ただし, } \mathrm{h} \geqq 0
\end{array}
$$

図ー10に，純せん断力を受ける試験体57体についてのh一e1関係 を示す。大局的にみて，ばらつきは大きいが(5) 式は概ね実験結果 の傾向を表わしていると言えよう。

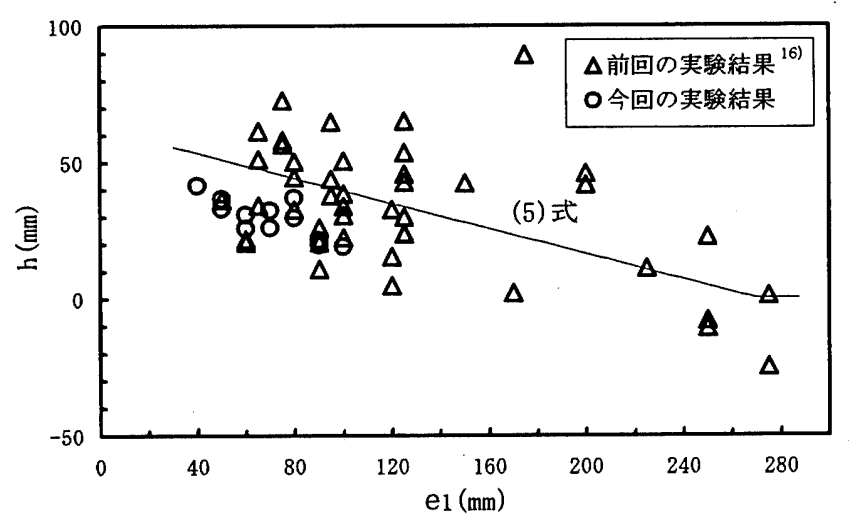

图-10 h-el関倸

従って, 基礎コンクリートのパンチングシアー破壊による終局せ ん断耐力を求める際の有効投影面積の実用的評価式として (4)，（5） 式が提案できる。また，パンチングシアー破壊した試験体57体の実 験耐力と (4)，(5) 式に基づく計算耐力Pcal（=cQu）の比Pmax/Pcal は0.53〜1.27の範囲にあり, 平均值は0.95であり, 比較的よく対応 しているものと判断される。

以上から，基礎コンクリートの終局せん断耐力の評価式として （2）式を用いること，ならびに有効投影面積を半円と長方形の和と することの妥当性が検証された。

次に, アンカーボルトの終局せん断耐力 bQu は, 秋山博士らの研 究成果 ${ }^{13)}$ を用した (6) 式より求める。

$$
\mathrm{bQu}=\mathrm{bAe} \cdot \mathrm{b} \sigma \mathrm{u} / \sqrt{3}
$$

本実験では，全ての試験体のアンカーボルトのせん断面が軸部で あることから，終局せん断耐力を求める際のbAeは軸断面䅡とし た。表ーにに示すように，アンカーボルトが破断した試験体№. 18， $26 ， 27 ， 47$ の 4 体と前回 ${ }^{16)}$ の2体, 合計6体の実験耐力と計算耐力 Pcal (=bQu) の比Pmax/Pcal は0.97〜1. 45の範囲にあり, 平均值は 1.23 であり，計算耐力は実験耐力を安全側に評価している。これ は, アンカーボルトの支圧によるコンクリート表層部の剥離破壊が 避けられないことから純せん断破壊になり難く, 幾分か曲げ引張破 壊に移行することによりbQuを上回るものと考えられるが，実験耐 力と計算耐力は概ね対忘していると言える。
以上から，アンカーボルトによる終局時のせん断抵抗力Quは，基 礎コンクリートのパンチングシアー破壊による耐力 cQu と:アンカー ボルトの耐力 bQu の小さい方で決定されるものとし，その場合の評 価式として(7)式が提案できる。

$\mathrm{Qu}=\min (\mathrm{cQu}, \mathrm{bQu})$

さて，前述の57体の実験結果の検討から，純せん断力を受けるア ンカーボルトが最大荷重に達し，同時に基礎コンクリートがせん断 破罗するときの最小縁端距離(限界縁端距離ue1 と呼ぶ; の実験式 は，本実験結果を加えて文献16）の式を修正し，（8）式のえうに表わ される。

$$
\begin{aligned}
\mathrm{ue} 1=\frac{1}{0.694}\left\{\sqrt{0.629 \mathrm{~d}^{2} \cdot \mathrm{b} \sigma \mathrm{u} / \sqrt{\mathrm{Fc}}+1497}-38.7\right\} \\
\text { ここに, } \mathrm{b} \sigma \mathrm{u}: \text { アンカーボルトの引張強度 }\left(\mathrm{N} / \mathrm{mm}^{2}\right) . \\
\mathrm{Fc} \because \text { コンクリートの压縮強度 }\left(\mathrm{N} / \mathrm{mm}^{2}\right) \\
\mathrm{d} \quad: \text { アンカーボルト軸径 }(\mathrm{mm})
\end{aligned}
$$

本実験では，各試験体の uelは，M12シリーズ：89mm(8.4d)， W1/2シリーズ : 95mm(7.4d), M16シリーズ : 116mm(7.4d), M20シリ ーズ : 163mm(8.3d)となる。el/uelが1.05以下の12体は甚整コンク リートがパンチングシアー破壊を起こし， el/uelが1.16以上の 4 体 はアンカーボルト軸部が破断している。以上のように，(8)式で与 えられる限界縁端距離は，本実験結果とも比較的よく対応してお り，実用設計上の目安となろう。

\section{3-2-3. 引張力とせん断力の組み合わせ応力を受ける場合}

引張力とせん断力の組み合わせ応力 $\left(\theta=30^{\circ}, 45^{\circ}, 60^{\circ}\right)$ を受け る試験体は 41 体で，そのうちアンカーボルトにより基礎コンクリー トがパンチングシアー破壊し, 最大荷重に達した試験体はNo. 2 $4,7 \sim 9,12 \sim 14,28,35 \sim 37,40 \sim 42,44 \sim 46,53 \sim 55,57 \sim$ $59 ， 61 \sim 65$ の30体である。その破壊状況は破壊形式1 3に示寸通り である。また, アンカーボルトが破断して最大荷重に達した試験体 はNo. 19〜21，29〜33，48～50の11体であり，その破壊状況は破壊 形式4に示す通りである。

ここでは，純引張力を受ける8体と純せん断力を受ける16体を含 めた65体 (表一1参照) と，前回 ${ }^{16)}$ の純せん断力を受ける4.7体を含め た合計112体の試験体に対する耐力評価法について検討刍る。純引 張力, 純せん断力, また, それらの組み合わせ応力を受けるアンカ 一ボルトの耐力評価式として，次に示す学会式 ${ }^{5) 8}(9)$ 式を適用す る。

$$
\left[\frac{T}{T u}\right]^{2}+\left[\frac{Q}{Q u}\right]^{2}=1
$$

図ー11に，全試験体 112 体についてのT/Tu一Q/Qu関係を示す。 なお, 実験值は, $\mathrm{T}=\mathrm{Pmax} \cdot \sin \theta, Q=\mathrm{Pmax} \cdot \cos \theta$ とし, 図中の記 号の白抜きはアンカーボルトによる基礎コンクリートのパンチン グシアー破壊を示し，黒整りはアンカーボルトの破断を示す。ま 
た, 組み合わせ态力を受ける場合の計算耐力Pcalは(10)式から求 める。

$$
\text { Pcal }=\frac{T u \cdot Q u}{\sqrt{T u^{2} \cdot \cos ^{2} \theta+Q u^{2} \cdot \sin ^{2} \theta}}
$$

図一11より, 純引張力を受ける試験体の計算耐力は実験耐力を比 較的よく評価していることが分かる。また，純せん断力を受ける試 験体のPmax/Pcalは0.7〜1.3の広範囲にあるが, 計算耐力は実験耐 力を概ね評価していると言えよう。さらに，組み合わせ态力を受け る試験体のうち, アンカーボルトが破断した試験体は全て計算耐力 を上回るが，基礎コンクリートがパンチングシアー破壊した試験体 は計算耐力を下回る傾向がみられる。しかしながら，全試験体の $\operatorname{Pmax} / \mathrm{Pcal}$ の平均值は0.95であり，実験耐力と計算耐力には相関が 認められる。

引張力とせん断力の組み合わせ応力を受ける41体のうちアンカ 一ボルトが破断した11体のPmax/Pcalは1.05〜1.35の範囲にあり，

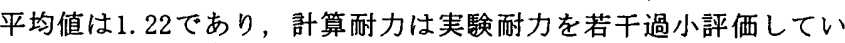

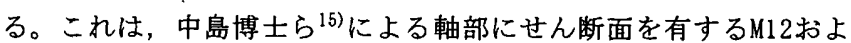
びM16のアンカーボルトの実験結果と似かよった傾向を示してい る。

基礎コンクリートがパンチングシアー破壊した 30 体のPmax/Pcal は0.56〜1.08の広範囲にあるが，平均值は0.8であり，計算耐力は 実験耐力を過大に評価している。なお゙, 試験体No. 25はcQu/bQu= 1.06 であるが基礎コンクリートがパンチングシアー破壊し，No. 29 はcQu/bQu=0.91であるが，アンカーボルトが破断している。これ は，cQuとbQuの值が近似しているためであろう。他の試験体の破填 は全て予測通りcQuとbQuの小さい方で決定された。

以上から, 引張力とせん断力の組み合わせ応力を受けるアンカー ボルトによる終局時のせん断抵抗力の評価式として (9) 式の妥当性 が検証された。

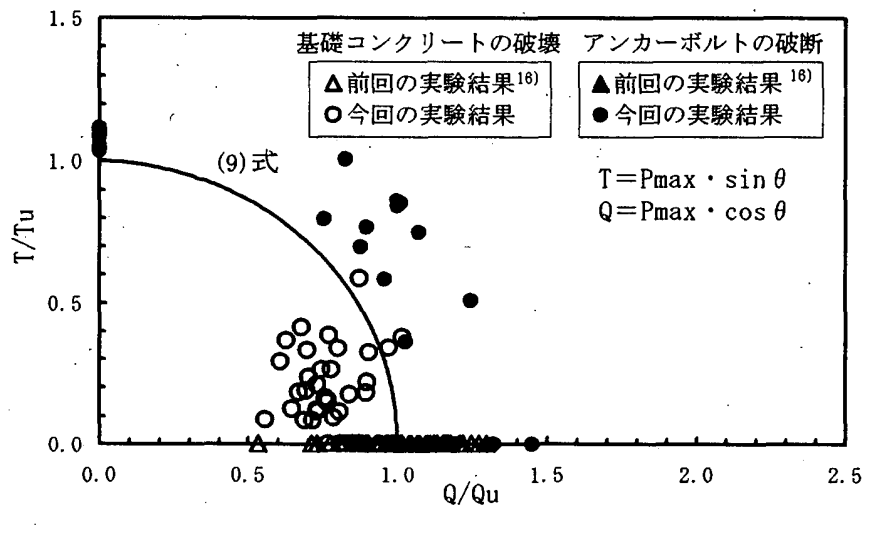

\section{3-2-4. 実用設計式}

現行の設計では，基礎コンク.リートのパンチングシアー破壊によ る終局せん断耐力 $\mathrm{cQu}$ の実用設計式として(11) 式备が提示されてい る。そこでは，有効投影面積を半円とし，低减係数 $\phi$ を0.6としてい る。

$$
\begin{aligned}
& c Q u=0.313 \phi A c o \sqrt{F c} \\
& \text { ここに, Aco： 半円の面積 }\left(\pi \mathrm{el}^{2} / 2\right)\left(\mathrm{mm}^{2}\right) \\
& \phi \quad: \text { 低减係数 }(=0.6)
\end{aligned}
$$

图ー12に，(11）式に基づく $\mathrm{T} / \mathrm{Tu}-\mathrm{Q} / \mathrm{Qu}$ 関係を示す。図にみられる ように，現行の設計法によると，全ての試験体が安全側に評価され るが, Pmax/Pcalの変動幅は1.05〜4.0 と著しく大きい。また， $\mathrm{cQu} / \mathrm{bQu}$ が $0.57 \sim 0.88$ の範囲にある試験体 4 体は，予測に反してアン カーボルト自体が破断した。以上から，有効投影面積を半円とし， 低减係数 $\phi$ を0.6とする(11) 式は実験結果を極端に過小評価するこ とが判明した。

本論文では，有効投影面積の評価式として (4)，（5)式を，また低 减係数として $\phi=0.6$, 実用設計に対する終局せん断耐力の評価 式として(12)式を提案する。

$$
\begin{aligned}
& \mathrm{cQu}=0.313 \phi \mathrm{Aco} \sqrt{\mathrm{Fc}} \\
& \Xi こ に, A c o: \pi \mathrm{el}^{2} / 2+2 \mathrm{el} \cdot \mathrm{h}\left(\mathrm{mm}^{2}\right) \\
& \phi \quad: \text { 低減倸数 }(=0.6)
\end{aligned}
$$

図ー13に，(12）式に基づく $\mathrm{T} / \mathrm{Tu}$ Q/Qu関係を示す。図にみられる ように，全ての試験体のPmax/Pcalの変動幅は0.89〜2.1 と幾分大き いが，Acoを半円とした図ー12の場合と比較してかなり小さくなっ ている。また，112体中110体(98.2\%)の試験体が安全側に評価され ている。
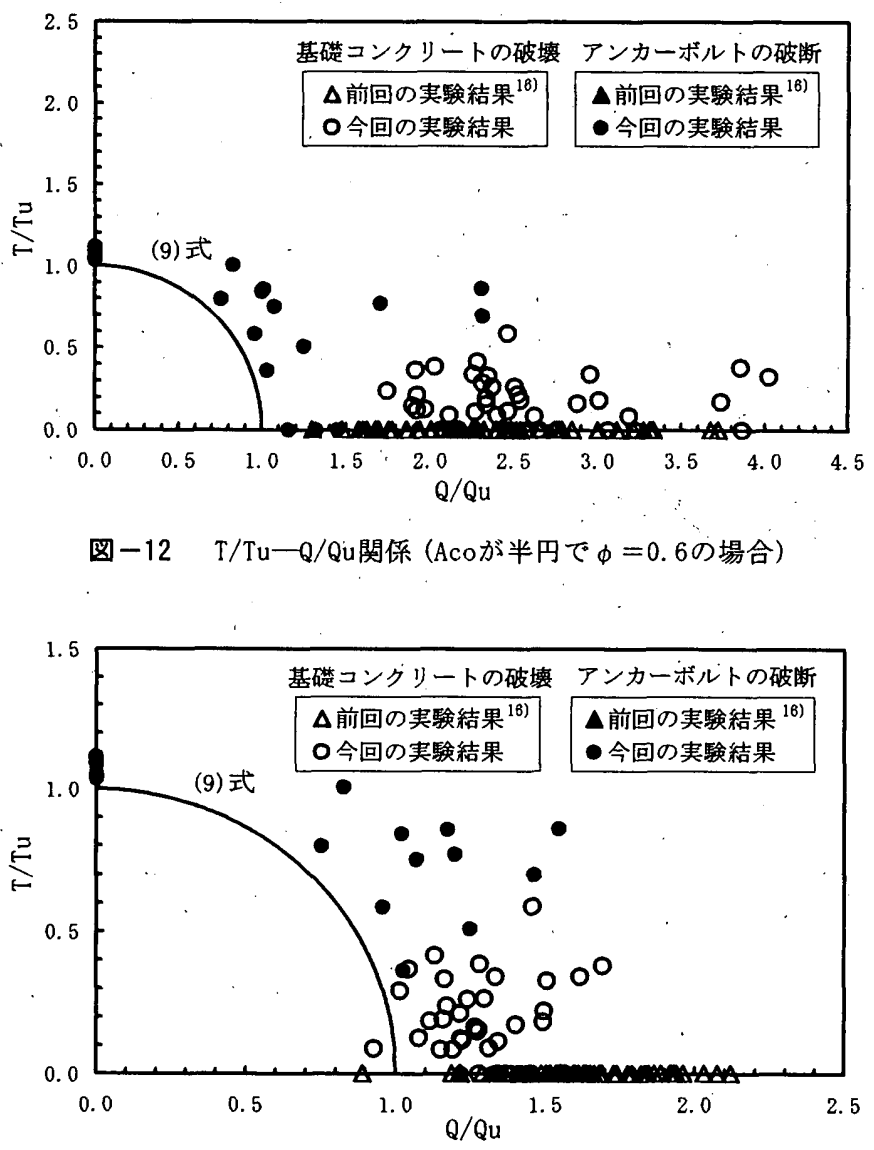

图-13 $\mathrm{T} / \mathrm{Tu}-\mathrm{Q} / \mathrm{Qu}$ 関係 $(A c o$ が半円十長方形で $\phi=0.6$ の場合 $)$ 


\section{4. まとめ}

本論文では，著者らの既往研究の資料に追加して，特に基整コン クリートの縁端距離が短い場合についての新たな実験を行い, アン カーボルトが引張力またはせん断力のいずれか一方，あるいはそれ らの組み合わせ応力を受ける場合について, 柱脚部の破壊形式の分 類および終局時のせん断抵抗力の評価方法について検討・考察し た。その結果，以下のような結論を得た。

（1）本実験における破塄形式は，基礎コンクリートがパンチング シアー破壊する形式1，2，3とアンカーボルトが破断する形式 $4 ， 5$ 5通りに分類される。

（2）アンカーボルトの終局引張耐力の評価式は，（1)式で評価でき る。

（3）基碳コンクリートがパンチングシアー破壊する場合の有効投 影面樌は，半円と長方形の和からなる (4)，(5) 式で評価でき る。

（4） アンカーボルトの終局せん断耐力は，秋山博士らの（6) 式で評 価できる。

（5）組み合わせ応力を受けるアンカーボルトによる終局時のせん 断抵抗力は，(9)式で評価できる。

（6）実用設計では，基礎コンクリートのパンチングシアー破壊耐 力を安全側に評価する(12)式が有用である。

\section{解辞}

本実験を行うにあたって九州産業大学の江口満氏および卒論生の 渡邊，楠原，石橋，田野，山下，亀岡諸氏の助力を得た。また、実 験资料の整理には(有)オフィスボンドの下瀬健二氏の協力を得た。 ここに記して謝意を表します。

\section{参考文献}

1）日本建築学会近㙨支部鉄骨構造部会：1995年兵庫累南部地震鉄骨造建 策物被害調查報告書, 1995.5

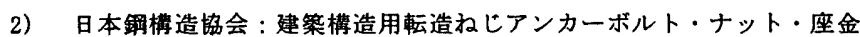
のセット, JSS II 13-2000, 1999，6

3）九谷和秀，増田貫志：鉄骨棈造露出形式柱脚におけるアンカーボルト

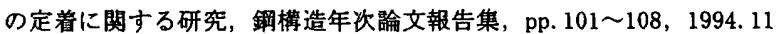

4）田中秀宣、三谷勲，大谷恭弘，藤水隆，伊藤倫夫：アンボンド型アン カーボルトを用いた露出型柱脚の構造性能，その7，柱脚・基礎梁接合 部の研究 (考察)，日本建穼学会大会学術請演梗概集，C-1, pp. 937〜 $938,2001.9$

5）日本建築学会：鋼構造接合部設計指針，2001.11

6）日本建築学会 : 各種合成㔍造設計指針・同解説, 1988.8

7) Patrick J.McMackin, Roger G.Slutter, and John W. Fisher : Headed Steel Anchor under Combined Loading : AISC Engineering Journal, Second Quarter, 1973

8）松崎育弘，矢野明義，菅家重夫，阿部保彦，宇佐美淡：機器配管用支 持構造物(埋込金物)の耐力に関する実験研究，その3，日本建築学会大 会学術講演梗概集，pp. 1813 1814，1980.9

9）松崎姢弘，矢野明義，菅家重夫，阿部保彦，宇佐美滋：機器配管用支 持棈造物 (埋込金物) の耐力に関する実験研究，その6，9，日本建策学 会大会学術講演梗概集, pp. 1567〜1568, pp. 1573〜1574，1981.9

10）河村博之, 浜田公也: 水平力を受ける埋込み鉄筋の耐力, 周辺コンク リートの大きさが与える影響について，その1，日本建築学会大会学術 講演梗概集，pp. 1901〜1902，1983.9

11）細川洋治：あと施エアンカーの強度と㑉性に関する基礎的研究, 東京 大学学位踚文, 1992.5

12) R.E.Klingner, J.A.Mendonca, J.B.Malik : Effect of Reinforcing
Details on the Shear Resistance of Anchor Bolts under Reversed Cycle Loading, ACI Journal, Vol. 7, 9, No. 1, pp. $3 \sim 12$, Jan.Feb. 1982

13）秋山宏, 黒沢稔, 和国信之, 西村功: 銅構造露出柱脚のせん断力抵抗, 日本建築学会稐文報告集，第338号，pp. 71～76，1984.4

14）九谷和秀，増田貫志：鉄骨棈造露出形式柱脚部の耐荷機構に関する実

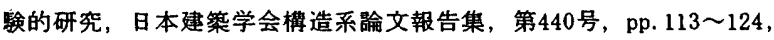
1992. 10

15）中島茂葴，大橋芳郎：引張力・せん断力・組み合わせ応力を受けるア ンカーボルト露出部の力学的性状に関する実験的研究(その2), 日本建 築学会大会学術講演梗概集, $\mathrm{C}-1, \quad$ pp. 477〜 478, 1997.9

16）河野久夫，檑俊明，增田贯志：埋め込みアンカーボルトのせん断耐力 に関する実験的研究，銅構造論文集，第3巻，第 12 号，pp. $31 \sim 38$ ， 1996. 12

17）河野久夫，九谷和秀，増田貫志：引張力とせん断力を受ける埋め込み アンカーボルトのカ学性状に関する実験的研究 : M16, M20のアンカー ボルト径に対して基礎コンクリートの縁端距離が短い場合, 日本建筑

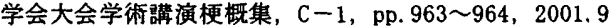

(2002年 9 月10日原稿受理，2003年 2 月 4 日採用決定） 